\title{
KEMAMPUAN MANAJERIAL, DAN UDAYA ORGANISASI TERHADAP KINERJA DOSEN DI LINGKUNGAN IAIN BENGKULU
}

\author{
Zulkarnain S \\ Dosen Institut Agama Islam Negeri Bengkulu \\ Email: zulkarnainsiainbkl@gmail.com
}

\begin{abstract}
This means that good personality results in improved lecturer performance. Managerial ability has a positive direct effect on performance. This means that good managerial skills lead to improved lecturer performance. Organizational culture has a direct positive effect on performance. This means that a good organizational culture, resulting in improved lecturer performance. Personality has a direct positive effect on organizational culture. This means that a good personality leads to an increase in organizational culture. Managerial ability has a direct positive effect on organizational culture. This means that good managerial skills, resulting in increased organizational culture.
\end{abstract}

Keywords: personality, managerial, lecturer performance.

Abstrak: Kepribadian berpengaruh langsung positif terhadap kinerja, Hal ini berarti bahwa kepribadian yang baik mengakibatkan meningkatnya kinerja dosen. Kemampuan manajerial berpengaruh langsung positif terhadap kinerja. Hal ini berarti bahwa kemampuan manajerial yang baik mengakibatkan meningkatnya kinerja dosen. Budaya organisasi berpengaruh langsung positif terhadap kinerja. Hal ini berarti bahwa budaya organisasi yang baik, mengakibatkan meningkatnya kinerja dosen. Kepribadian berpengaruh langsung positif terhadap budaya organisasi. Hal ini berarti bahwa kepribadian yang baik mengakibatkan meningkatnya budaya organisasi. Kemampuan manajerial berpengaruh langsung positif terhadap budaya organisasi. Hal ini berarti bahwa kemampuan manajerial yang baik, mengakibatkan meningkatnya budaya organisasi.

Kata kunci: kepribadian, manajerial, kinerja dosen.

\section{Pendahuluan}

Khusus di lingkungan PTAI dalam hal ini UIN, IAIN maupun STAIN yang perlu mendapat penataan dan peningkatan antara lain adalah masalah kualifikasi dosen. Karena kekuatan utama perguruan tinggi dalam kehidupan di era pasar bebas yang ditandai oleh sifat ketidak pastian yang tinggi dan paradoksial, terletak pada kekuatan sumber daya dosen. Peran dosen berada dalam posisi yang paling strategis. Oleh karena itu, dalam upaya peningkatan mutu pendidikan tinggi khususnya di PTAI, dosen seharusnya menjadi pusat perhatian seksama.

Jumlah doktor yang mengajar di Perguruan Tinggi Keagamaan Islam di Indonesia belum memadai. Padahal, untuk meningkatkan mutu pendidikan Islam, dibutuhkan dosen yang berkualitas dan kompeten secara keilmuan. Data Kementerian Agama menunjukkan, jumlah dosen yang tersebar di Perguruan Tinggi Keagamaan Islam (PTKI) negeri dan swasta mencapai 29.824 pengajar. Dari jumlah tersebut, dosen yang berpendidikan doktor baru berjumlah 2.920 orang (9,7 persen). Menurut Direktur Jenderal Pendidikan Islam Kamaruddin Amin, "Kualitas dan kompetensi dosen masih menjadi masalah krusial dalam peningkatan mutu PTKI. Karena itu, jumlah doktor perlu ditambah lagi. Seharusnya, dosen yang mengajar bergelar doktor agar mampu melakukan transformasi di dunia pendidikan"."

Upaya pembenahan kurikulum, perbaikan prasarana dan sarana, manajemen perguruan tinggi merupakan hal penting, namun tanpa adanya dosen yang bermutu dan sejahtera, semuanya itu menjadi kurang bermakna. Salah satu faktor penting yang mempengaruhi mutu pendidikan tinggi

'Kamaruddin Amin. "Kampus Masih Kekurangan Doktor". http:// edukasi.kompas.com/read /2015/ 08/25/ 20210061/Kampus. Masih.Kekurangan. Doktor. (diakses 7 Mei 2016). 
adalah dosen yang bermutu.

Dosen yang bermutu dapat diukur dengan lima faktor utama, yaitu kemampuan professional, upaya professional, kesesuaian antara waktu yang dicurahkan untuk kegiatan professional, kesesuaian antara keahlian dan pekerjaannya, serta kesejahteraan yang memadai.

Di era pasar, pengelolaan perguruan tinggi harus ditujukan untuk mengantisipasi kehidupan yang penuh ketidakpastian, paradoksial, dan penuh persaingan, dengan upaya memberdayakan dan meningkatkan kualitas sumber daya dosen. Hal ini tentu saja tidak mudah. Rully Indrawan memberikan gambaran bahwa dosen adalah salah satu elemen strategis bagi kehidupan sebuah perguruan tinggi (PT), selain: Program Akademis, Perpustakaan, dan Pendanaan. Sangat sulit dibayangkan bagaimana suatu PT dapat berkembang dengan baik, tanpa didahului oleh dinamika dan perkembangan yang sepadan antara keempat elemen strategis tersebut. ${ }^{2}$ Posisi dosen dalam konstelasi perkembangan tersebut lebih penting peranannya, bila dikaitkan dengan asumsi bahwa sumber daya manusia merupakan kunci penting bagi perkembangan sistem organisasi.

Kinerja dosen saat ini banyak dinilai kurang memuaskan, baik oleh mahasiswa ataupun masyarakat pada umumnya. Dari mulai tingkat disiplin sampai pada kemampuan dalam pengelolaan pembelajaran yang lemah, dan dari penguasaan materi ajar yang minim sampai pada lemahnya budaya menulis, sehingga gambaran umum terhadap profesi dosen tersebut lebih banyak diposisikan sebagai transformator ilmu pengetahuan semata, bukan produsen ilmu. Demikian juga yang ditransformasikannyapun lebih banyak ilmu pengetahuan yang sudah out of date (basi). Keadaan ini sudah barang tentu berimplikasi pada mutu proses pembelajaran, dan akhirnya bermuara pada rendahnya mutu PT secara menyeluruh.

Direktorat Jenderal Pendidikan Tinggi (Dikti), 2011 menyatakan bahwa jumlah dosen di Indonesia sudah melebihi 180.000 orang dan diperkirakan hanya 1,1 persen yang mampu meneliti dengan layak. Sehingga kontribusi Indonesia dan perkembangan ilmu pengetahuan sangat rendah, hal ini dapat dilihat bahwa Indonesia berada peringkat ke65 dengan jumlah yang dihasilkan Indonesia hanya

${ }^{2}$ Lihat Makalah: Percik Pengalaman Mengurus Jabatan Fungsional, disampaikan pada penataran Penilaian Angka Kredit Jabatan Fungsional Dosen, Kopertis Wilayah IV, 27-28 Mei 2003,h. 2. sebanyak 12.871 artikel, sebagai perbandingan, di ingkungan ASEAN Indonesia berada pada posisi di bawah Thailand dan Malaysia yang menduduki posisi ke 42 dan $43 .{ }^{3}$

Jika dibandingkan dengan jumlah dosen di Indonesia, jumlah karya ilmiah tersebut memang masih mengkhawatirkan. Jika dihitung per kepala dosen, maka jumlah dokumen per kapitanya hanya sebesar 0,07. Artinya, tujuh paper dihasilkan oleh 100 orang dosen di Indonesia. Indikator ini menyisakan pekerjaan rumah bagi para pendidik, terutama dosen yang mengemban Tri Dharma Perguruan Tinggi, salah satunya adalah penelitian, dan salah satu tahap penting dalam penelitian adalah publikasi.

Banyak yang menjadi faktor penyebab rendahnya kinerja dosen, dari mulai sistem rekruitmen, iklim PT yang tidak kondusif untuk mengembangkan budaya akademis, sampai pada imbalan kerja yang memadai. Hal yang terakhir ini adalah salah satu penyebab mengapa para dosen lebih banyak menghabiskan waktu untuk terlibat dalam berbagai kegiatan di luar kampus, baik untuk mengerjakan proyek-proyek maupun berprofesi ganda, yang kadang-kadang tidak memiliki kaitan langsung dengan tugas dan fungsi keakademisiannya. Jika ditarik lebih jauh ke belakang lagi, lemahnya sistem imbalan kerja ini juga diduga menjadi penyebab, mengapa profesi dosen kurang diminati oleh para lulusan terbaik. Para lulusan terbaik lebih senang berprofesi di luar dunia kependidikan yang lebih menjanjikan secara finasial, ketimbang menjadi dosen.

Dalam konteks tersebut, sistem pendidikan tinggi di Indonesia belum mempunyai standar ukuran produktivitas maupun efisiensinya karena adanya nilai-nilai yang dipandang tidak dapat dihitung secara material pada produktivitas perguruan tinggi tersebut. Namun demikian, di era pasar bebas pada abad ke-21 ini, perguruan tinggi termasuk PTAI harus dapat mengantisipasi berbagai tuntutan:

Pertama, persaingan tenaga kerja yang mengglobal, yang masuk bersama penanaman modal asing sebagai konsekuensi diberlakukannya perjanjian ASEAN-AFTA (mulai tahun 2002), WTO-GATT dan APEC (mulai tahun 2010). Untuk mengantisipasi hal ini, perguruan tinggi harus mampu menjamin mutu lulusan atau hasil didiknya di berbagai bidang profesi untuk memperoleh sertifikasi profesi atau untuk memperoleh sertifikat profesi sebagai syarat untuk 
memperoleh hak bekerja sesuai dengan kompetensi kepakaran yang dipelajarinya di perguruan tinggi.

Kedua, perguruan tinggi harus mampu menyiapkan hasil didik yang kompetennya dinilai tidak hanya atas dasar penguasaan pengetahuan dan keterampilan, tetapi juga penguasaan sikap dan semangat kerja, kemampuan berkomunikasi, interpersonal, kepemimpinan, kerjasama tim, analisis permasalahan dan sintesis pemecahan masalah, disiplin, teknologi informasi, pemanfaatan komputer, fleksibilitas kerja, mampu mengelola kekaburan masalah, dapat bekerja dalam berbagai budaya, pemahaman globalisasi, terlatih dalam etika kerja, serta menguasai bahasa asing sebagai bahasa utama kedua.

Ketiga, perguruan tinggi diharapkan dapat menyelenggarakan program yang lebih humanis. Makna humanis dalam hal ini memberi peluang yang lebih besar bagi anggota masyarakat untuk dapat memperoleh manfaat dari penyelenggaraan pendidikan, jaminan mutu pendidikan, dan kebutuhan masyarakat, menjawab kebutuhan persamaan hak, pemenuhan perspektif internasional dan biaya pendidikan yang sepadan.

Untuk itu kurikulum inti berada dalam suatu situasi dimana sasaran penguasaan teknologi menjadi bagian dari kebudayaan berikut dengan implikasinya sebagai bekal dasar kompetensi yang diperlukan seseorang menemukan kemampuan makna diri dalam berkehidupan.

Keempat, kurikulum sebagai pedoman penyelenggaraan program studi harus dapat menjaga keserasian antara program yang diselenggarakan dengan aspirasi masyarakat. Hal ini dapat ditempuh dengan cara meniadakan ketidakterpautan dan menghindarkan beban berlebihan dalam proses pembelajaran, tetapi secara umum dapat mencirikan tugas khusus dan misi yang diembannya untuk setiap jenjang pendidikan.

Kelima, penyelenggaraan pendidikan tinggi diharapkan mampu menampung politisasi pendidikan, kebutuhan belajar sepanjang hayat, internasionalisasi pendidikan tinggi dalam makna reconvergent phase of education.

Politisasi pendidikan tinggi terjadi oleh karena masyarakat menyadari bahwa pendidikan merupakan jembatan untuk kemakmuran ekonomi di masa depan, pilihan piranti untuk mengatasi pengangguran, menggapai teknologi dan ilmu yang maju, prasyarat vitalitas kebudayaan untuk meningkatkan kenyamanan kehidupan masyarakat, dan pengaman nilai-nilai demokratis.

Dalam penelitian ini hanya dibatasi pada tiga variabel yang diduga mempengaruhi kinerja dosen tersebut. Ketiga variabel tersebut: kepribadian, kemampuan manajerial, dan budaya organisasi. Kinerja dosen di lingkungan IAIN Bengkulu diduga dipengaruhi oleh kepribadian, kemampuan manajerial, dan budaya organisasi. Oleh karena itu, untuk mengetahui kinerja dosen di IAIN Bengkulu, maka peneliti memandang perlu dilaksanakan penelitian ini.

\section{Rumusan Masalah}

Berdasarkan batasan masalah sebagaimana diuraikan di atas, maka permasalahan penelitian ini dapat dirumuskan:

1. Apakah kepribadian berpengaruh langsung terhadap kinerja?

2. Apakah kemampuan manajerial berpengaruh langsung terhadap kinerja?

3. Apakah budaya organiasi berpengaruh langsung terhadap kinerja?

4. Apakah kepribadian berpengaruh langsung terhadap budaya organisasi?

5. Apakah kemampuan manajerial berpengaruh langsung terhadap budaya organisasi?

\section{Tujuan Penelitian}

a. Melalui penelitian ini diharapkan akan dapat diketahui bagaimana kepribadian dan kemampuan manajerial mempengaruhi kinerja dosen. Dengan demikian dapat dijadikan bahan bagi pimpinan organisasi dilingkungan IAIN Bengkulu. Dan dapat memberikan wawasan didalam penelitian mengenai kepribadian dan kemampuan kerja terhadap kinerja dosen.

b. Melalui penelitian ini diharapkan dapat diketaui bagaimana budaya organisasi dapat mempengaruhi kinerja dosen. Dan dapat memberikan wawasan dalam penelitian mengenai pentingnya budaya organisasi mempengaruhi kinerja dosen.

\section{Metode Penelitian}

Metode penelitian ini menggunakan survei metode kausal dengan analisis jalur (path analysis). Penggunaan analisis jalur dimaksudkan untuk menganalisis pola hubungan kausal langsung, kausal tidak langsung, maupun pola hubungan bersama seperangkat variabel (variabel eksogen) terhadap variabel akibat (variabel endogen). Pada penelitian ini terdapat tiga variabel bebas (eksogen) yaitu kepribadian (X1), kemampuan manajerial (X2) dan budaya organisasi (X3) dengan satu variabel terikat (endogen) yaitu kinerja dosen (Y). Lebih lanjut, 


\section{Zulkarnain S I Kemampuan Manajerial, dan Upaya Organisasi 87}

analisis jalur memiliki kegunaan untuk mengetahui pengaruh derajat antara hubungan variabel bebas (independent variable) dengan variabel terikat (dependent variable). Berdasarkan metode dan teknik analisis yang digunakan, maka disusunlah model hipotetik hubungan kausal antar variabel.

\section{Kajian Teoritik}

\section{Pengertian Kinerja}

Secara harfiah, kinerja merupakan terjemahan dari kata kineta enerji kerja yang padanannya adalah performance. "Kinerja adalah keluaran yang dihasilkan oleh fungsi-fungsi atau indikatorindikator suatu pekerjaan atau suatu profesi dalam waktu tertentu". ${ }^{4}$ Kinerja dosen di lingkungan IAIN Bengkulu sangat diperlukan dalam pelaksanaan tugas, wewenang dan tanggung jawabnya dalam mencapai tujuan akademik. Dengan kata lain, optimalisasi pencapaian kemampuan dosen dalam menyelesaikan pengelolaan program akademik. Untuk mendapatkan gambaran yang lebih lengkap dan konfrehensif terhadap makna kinerja akan diuraikan dan didapat dari berbagai pendapat.

Kinerja (performance) dosen merupakan bagian penting dalam pencapaian prestasi kerja. Robbin mengemukakan bahwa "keberhasilan dalam melakukan suatu pekerjaan sangat ditentukan oleh kinerja."5 Dengan kata lain kinerja merupakan faktor yang menentukan keberhasilan. Beberapa definisi kinerja dikaitkan dengan berbagai hal yang berhubungan dengan organisasi misal; hasil kerja atau prestasi kerja. Namun, sebenarnya kinerja mempunyai makna yang lebih luas, bukan hanya hasil kerja, tetapi termasuk bagaimana proses pekerjaan berlangsung. Menurut Mohmen West dan Lawler, pengertian kinerja adalah:

Karakter atau penampilan kegiatan yang menggambarkan konsistensi dengan konteks pekerjaan, tingkah laku, hasil kerja, kompeten dan tuntas. Tidak ada pekerjaan yang terbengkalai dan semuanya dilakukan secara terpadu sebagai sesuatu yang harus terjadi dalam kinerja. ${ }^{6}$

${ }^{4}$ Wirawan, Evaluasi Kinerja Sumber Daya Manusia, Teori, Aplikasi, dan Penelitian (Jakarta: Selemba Empat, 2009), h. 5.

${ }^{5}$ Stephen P. Robbin, Essentials of Organizational Behavior (New Jersey: Prentice-Hall Internatioanl Inc, 1997), h. 231.

${ }^{6}$ Aban M. Mohrman, M. Resnick West, dan Edward E. Lawler, Designing Performance Appraisal Systems (San Francisco: Jossey Bass, 1989), h. 110.
Pendapat lain tentang kinerja menurut Armstrong dan Baron mendefinisikan bahwa "kinerja merupakan hasil kerja dan tingkah laku". ${ }^{7}$ Begitu juga pendapat Wibowo tentang kinerja adalah "tentang apa yang dikerjakan dan bagaimana cara mengerjakan".

\section{Kemampuan Manajerial}

Colquitt Lepine dan Wesson mengartikan kemampuan atau (acuity) refers to the relatively stable capabilities people have to perform a particular range of different but related activities. ${ }^{9}$ Kemampuan seperti dimaksud Colquitt dkk dapat dilakukan melalui pendidikan dan pelatihan serta pengalaman. Lebih lanjut Colquitt dkk menjelaskan bahwa:

Kemampuan dapat dibagi ke dalam tiga kategori; (1) kemampuan kognitif, yaitu kemampuan menghubungkan aplikasi pengetahuan dalam mengatasi masalah; (2) Kemampuan emosional, yaitu kemampuan untuk dapat beradaptasi dan mempengaruhi orang lain di lingkungannya; dan (3) kemampuan fisik, yaitu tercermin dari kekuatan fisik/lahiriyah seseorang. ${ }^{10}$

Pengertian ini menunjukkan bahwa kemampuan seseorang tercermin pada kamampuan kognitif, kemampuan emosional dan kemampuan fisik (psikomotor).

\section{Budaya Organisasi}

Dosen merupakan bagian dari masyarakat akademik didalam menjalankan tugas tridharma perguruan tinggi yaitu pengajaran, penelitian dan pengabdian pada masyarakat tidak dapat dipisahkan dari aturan, falsafah, nilai, norma, kebiasaan ataupun budaya yang ada pada lingkungan perguruan tinggi.

Disuatu perguruan tinggi haruslah memiliki budaya organisasi untuk membentuk suatu aturan / pedoman dalam berpikir dan bertindak agar tercapai tujuan yang ditetapkan. Selain itu, tekanan utama dalam perubahan dan pengembangan budaya organisasi adalah mencoba untuk mengubah nila-nilai, sikap dan perilaku antar dosen secara keseluruhan.

${ }^{7}$ Micahel Amstrong dan Angela Baron, Performance Management (London: Institute of Personal and Depelopment, 1998), h.15

${ }^{8}$ Wibowo, Manajemen Kinerja (Jakarta: Rajawali pers, 2012), h. 7.

${ }^{9}$ Colquitt, Lepine dan Wesson, op cit, h. 337

${ }^{10}$ Tbid., hh. 344-351. 
Secara konseptual, budaya organisasi merupakan salah satu faktor penting yang dapat menentukan efektivitas dan efisiensi kerja organisasi sehingga tujuan yang diinginkan dapat tercapai secara optimal. Oleh karena itu, setiap organisasi harus mengembangkan budaya organisasai yang mantap, yang dapat dipahami dan diterima internal maupun eksternal. Dengan demikian, budaya organisasi dapat berfungsi secara efektif dalam rangka mencapai maksud dan tujuan organisasi. Bahkan, budaya organisasi dapat menjadi landasan pengembangan pola kerja dan pola hubungan antara sesama anggota organisasi lain.

Budaya dalam konteks organisasi disebut dengan budaya organisasi (organization culture), dalam konteks perusahaan, diistilahkan dengan budaya perusahaan (corporate culture), pada lembaga pendidikan/institut disebut dengan budaya sekolah (school culture), tentu saja berbeda dengan kajian budaya antropologi sosial atau organisasi perusahaan, pada organisasi institut fokus pada perilaku, sehingga memunculkan kajian perilaku organisasi (organization behavior), pada suatu organisasi disamping terdapat hal-hal yang bersifat hard juga ada yang bersifat soft, aspek-aspek termasuk hard antara lain adalah struktur organisasi, aturanaturan, kebijakan, teknologi, dan keuangan, hal-hal tersebut dapat diukur, dikualifikasikan serta dikontrol dengan relatief mudah, sedangkan hal-hal yang soft adalah yang terkait dengan the human side of organization (aspek manusiawi dalam organisasi) meliputi nilai-nilai keyakinan, budaya serta normanorma perilaku.

\section{Pembahasan}

Berdasarkan hasil perhitungan analisis jalur antar variabel ditemukan secara umum terdapat pengaruh variabel eksogenus terhadap variabel endogenus.Dalam penelitian ini yang menjadi variabel eksogenus adalah kepribadian, kemampuan manajerial, budaya organisasi.Sedangkan variabel endogenus dalah variabel kinerja dosen.

Hasil penelitian menunjukkan baik kepribadian, kemampuan manajerial dan budaya organisasi berpengaruh secara signifikan terhadap kinerja dosen. Dengan demikian ke tiga variabel tersebut dapat digunakan untuk meningkatkan kinerja dosen.

\section{Kepribadian terhadap Kinerja Dosen}

Kepribadian merupakan cermin jati diri yang meliputi pada tingkah laku seseorang dalam kesehariannya.Hasil penelitian menunjukkan secara empiris bahwa kepribadian seorang dosen berpengaruh langsung terhadap kinerja dosen tersebut.
Dalam arti semakin baiknya kepribadian dosen di lingkungan IAIN Bengkulu, maka akan semakin tinggi kinerja yang dihasilkan. Sebaliknya semakin buruknya kepribadian dosen di lingkungan IAIN Bengkulu, maka akan semakin rendah pula kinerja yang dihasilkan.

Temuan penelitian ini sejalan dengan hasil penelitian Arwan di Sumatera Selatan dengan judul Kinerja Pejabat Dinas Pendidikan Se-provinsi Sumatera Selatan menunjukkan bahwa kepribadian berpengaruh positif terhadap kinerja pejabat dinas pendidikan. Dengan adanya pengaruh langsung kepribadian terhadap kinerja pejabat eselon III, maka perlu mendorong munculnya kesadaran tentang pentingnya peningkatan kinerja yang bersumber pada kepribadian. Peningkatan kepribadian dilakukan dengan cara mendorong pejabat eselon III untuk menghayati tugas dan pengabdiannya. Seiring dengan itu kepribadian pejabat eselon III perlu terus ditingkatkan. ${ }^{11} \mathrm{Hal}$ ini akan dapat meningkatkan rasa percaya diri, mengendalikan orang lain, memupuk kebersamaan, mengekspresikan emosi, menuntaskan pekerjaan dan kekuatan untuk meraih sukses.

Hasil penelitian ini juga mendukung teori tentang kepribadian yang telah dinyatakan oleh para ahli tentang kepribadian.Menurut Jess dan Gregory, kepribadian dapat dipahami dengan pola sifat dan karakteristik tertentu, yang relatif permanen dan memberikan baik konsistensi maupun individualitas pada perilaku seseorang. ${ }^{12}$ Dalam pengertian ini terdapat dua hal yang penting yaitu sifat dan karakteristik.Sifat merupakan faktor penyebab adanya perbedaan antar individu dalam perilaku, konsisten dari waktu ke waktu dan stabilitas dalam berbagai situasi.Sedangkan karakter merupakan kualitas tertentu yang dimiliki seseorang termasuk dalam karakter sendiri seperti tempramen, fisik, dan kecerdasan.Dalam perspektif demikian, maka Abraham berpendapat bahwa kepribadian sebagai pola pikir, perasaan dan perilaku yang sudah berurat-akar mendalam dan relatif menetap. ${ }^{13}$

Mullins berpendapat, kepribadian adalah kemantapan karakteristik yang menjelaskan tentang hal-hal yang harus dimiliki oleh seseorang seperti kemandirian, kontrol diri, dan sikap konsisten. ${ }^{14}$

\footnotetext{
${ }^{11}$ Arwan, op. cit., h. 111

${ }^{12}$ Jess Feist dan Gregory J Feist, op. cit., h. 4.

${ }^{13}$ Amit Abraham, op. cit., h.1.
${ }^{14}$ Laurie J. Mullins, Management and Organizational Behavior, Seventh Edition (London: Prentice Hall, 2005), h. 339.
} 


\section{Zulkarnain S I Kemampuan Manajerial, dan Upaya Organisasi 89}

Dengan demikian kepribadian akan melahirkan kemandirian, kemampuan untuk mengontrol diri dan kepribadian akan memunculkan sikap konsistensi.

Menurut Mohmen West dan Lawler bahwa, pengertian kinerja adalah karakter atau penampilan kegiatan yang menggambarkan konsisten dengan konteks pekerjaan, tingkah laku, hasil kerja, kompeten dan tuntas.Tidak ada pekerjaan yang terbengkalai dan semuanya dilakukan secara terpadu sebagai sesuatu yang harus terjadi dalam kinerja. ${ }^{15}$

Pendapat lain tentang kinerja menurut Armstrong dan Baron mendefinisikan bahwa kinerja merupakan hasil kerja dan tingkah laku. ${ }^{16}$ Begitu juga pendapat Wibowo tentang kinerja adalah tentang apa yang dikerjakan dan bagaimana cara mengerjakan. $\frac{17}{}$

Dari berbagai teori tersebut didapatkan hubungan yang erat antara keperibadian yang meliputi pola pikir, perasaan dan tingkah laku dengan kinerja seseorang. Apabila seseorang memiliki pola pikir, perasaan dan tingkah laku yang stabil dan mantap, maka akan memunculkan karakteristik seseorang yang mandiri, mampu untuk mengontrol diri dan akan memunculkan sikap konsistensi dalam pekerjaan dan kehidupan sehari-hari. Sehingga kepribadian seseorang dapat mempengaruhi peningkatan atau penurunan kinerja orang tersebut di suatu lingkungan organisasi.

\section{Kemampuan manajerial terhadap kinerja dosen}

Hasil penelitian menunjukkan bahwa kemampuan manajerial berpengaruh secara langsung terhadap kinerja dosen. Hasil penelitian ini memperkuat teori Rivai yang menegaskan bahwa keterampilan manjerial yang efektif ada tiga aspek: (1) Keterampilan Teknis. Keterampilan ini adalah pengetahuan mengenai metode-metode, prosesproses, prosedur serta teknis kegiatan khusus dari unit organisasi. (2) Keterampilan antar pribadi. Keterampilan ini adalah pengetahuan perilaku manusia dan proses-proses kelompok, kemampuan untuk mengerti perasaan, sikap serta motivasi orang lain dan kemampuan untuk mengkomunikasikan dengan jelas dan persuasif. (3) Keterampilan Konseptu-

\footnotetext{
${ }^{15}$ Aban M. Mohrman, M. Resnick West, dan Edward E. Lawler, DesigningPerformance Appraisal Systems (San Francisco : Jossey Bass, 1989), h. 110.

${ }^{16}$ Micahel Amstrong dan Angela Baron, PerformanceManagement (London : Institute of Personal and Depelopment, 1998), h.15

${ }^{17}$ Wibowo, Manajemen Kinerja (Jakarta: Rajawali pers, 2012), h. 7.
}

al, yaitu kemampuan kognitif, seperti kemampuan analisis, berpikir logis, membuat konsep, pemikiran induktif dan pemikiran deduktif. Dalam pengertian secara umum, keterampilan konsepual termasuk penilaian yang efesien dan efektif, dapat melihat ke depan, kreatif dan kemampuan untuk menemukan arti dan sukses mengelola peristiwa-persitiwa yang ambisius dan tidak pasti. ${ }^{18}$

Sedangkan Yukl berpendapat bahwa manager adalah mereka yang menghargai stabilitas, keteraturan dan efisiensi.Manajer sangat memperhatikan bagaimana sesuatu dapat diselesaikan, dan mereka berusaha untuk membuat orang dapat melakukannya dengan baik. ${ }^{19}$ Bila menganalisa peran ini, maka kemampuan manajerial terkait dengan kemampuan mengambil keputusan, mengalokasikan sumber daya manusia maupun sumber daya yang lain serta mengatur aktivitas staf, sehingga berbagai pekerjaan dapat dilaksanakan dengan efesien dan efektif serta kinerja pun menjadi meningkat di dalam suatu organisasi. Jika seorang dosen memiliki kemampuan manajerial dalam mengatur aktifitas dirinya, staf dan mahasiswa dengan baik, maka kinerja dosen akan lebih meningkat, efektif dan efesien dalam menyelesaikan tugastugasnya sebagai tenaga pengajar dan pembimbing.

\section{Budaya organisasi terhadap kinerja dosen}

Hasil penelitian menunjukkan secara empiris bahwa budaya organisasi berpengaruh secara positif dan signifikan terhadap kinerja dosen. Dalam arti semakin baik budaya organisasi yang dirasakan oleh dosen maka akan semakin baik pula kinerja yang mereka hasilkan. Demikian pula sebaliknya, semakin tidak baik budaya organisasi yang dirasakan oleh dosen, maka akan semakin tidak baik pula kinerja yang mereka hasilkan.

Hasil penelitian ini sejalan dengan hasil penelitian Suwito dengan judul Pengaruh Budaya Organisasi, Kepemimpinan dan Motivasi terhadap Kinerja (Studi Kausal pada Guru SMP Negeri Kota Semarang) antara lain menyimpulkan bahwa budaya organisasi berpengaruh langsung positif terhadap kinerja. Artinya, budaya organisasi yang tinggi akan menyebabkan tercipta atau terwujudnya kinerja para anggota organisasi yang tinggi. ${ }^{20}$ Apabila ciriciri dan budaya organisasi sekolah dapat dilaksanakan secara konsisten dan konsekuen, niscaya buda-

\footnotetext{
${ }^{18}$ Rivai, op cit, h. 33 .

${ }^{19} \mathrm{Gary}$ YukI, Leadership in Organization. Fith Editation, alih bahasa Budi Supriyanto (Jakarta: Intan Sejati, 2005), h. 7. ${ }^{20}$ Pramono Suwito Eko, op. cit., h. 201.
} 
ya organisasi sekolah yang tinggi dapat diwujudkan secara nyata. Budaya organisasi sekolah yang tinggi pada akhirnya akan menyebabkan terciptanya kinerja para guru yang tinggi.

Sesuai pula dengan hasil penellitian Sumarsih yang berjudul Pengaruh Budaya Organisasi, Kepuasan Kerja, Komitmen Organisasi dan Kerjasama Tim Terhadap Kinerja Pengawas Sekolah Dasar di Provinsi Bengkulu menyatakan bahwa budaya organisasi berpengaruh langsung positif terhadap kinerja pengawas. Artinya, budaya organisasi yang baik menyebabkan terwujudnya kinerja pengawas yang baik pula. ${ }^{21}$ Temuan ini memberikan implikasi bagi pimpinan jajaran depdikbud untuk memberi dukungan kepada kualitas budaya organisasi yang perlu terus diperbaiki antara lain kualitas komunikasi, kualitas kepercayaan satu sama lainnya, kualitas kehesivitas, kedisiplinan, ketaatan terhadap aturan. Kinerja pengawas akan dapat dipertahankan dan terus ditingkatkan jika mereka sudah tertanam secara mendalam di dalam dirinya nilai-nilai organisasi dan nilai-nilai tersebut diimplementasikan dalam melaksanakan tugas dan tanggung jawab sebagai pengawas.

Sondang P. Siagian berpendapat tentang teori budaya organisasi, yaitu "perilaku dan kebiasaan kerja setiap anggota sudah berlangsung sejak berdirinya organisasi, yang terus dipertahankan dan diterapkan hingga menjadi budaya organisasi." 22

Schen menekankan bahwa budaya organisasi melibatkan didalamnya asusi-asumsi, adaptasi, persepsi-persepsi yang dipelajari oleh karyawan secara terus menerus. Budaya organisasi mencakup didalamnya harapan-harapan bersama (shared expections), nilai-nilai dan sikap-sikap yang berkembang dan mempengaruhi individu, kelompok dan proses organisasi. Budaya organisasi merupakan sistem nilai organisasi dan akan mempengaruhi cara pekerjaan dilakukan dan cara para karyawan berperilaku. ${ }^{23}$

Organisasi yang kuat dan eksis, biasanya telah memiliki budaya organisasi yang dikembangkan berdasarkan nilai, norma, aturan, sifat, ciri, karakteristik, maupun tujuan organisasi sehingga mampu membentuk sikap dan perilaku yang baik bagi para anggotanya dalam melaksanakan tugas-tugas mereka dan memberikan kinerja serta dedikasi yan tinggi bagi organisasinya. Sebaliknya, organisasi

\footnotetext{
${ }^{21}$ Sumarsih, op. cit., h. 205

${ }^{22}$ Sondang Siagian P. op.cit.

${ }^{23}$ Benyamin Scheneider, Personality And Organizations. New York Lawrence Ebaum Associate, 2004.
}

yang belum memilki budaya organisasi yang dikembangkan berdasarkan nilai, norma, aturan, sifat, ciri, karakteristik, maupun tujuan organisasi, maka tidak akan mampu membentuk sikap dan perilaku yang baik bagi para anggotanya dalam melaksanakan tugas-tugas mereka dan memberikan kinerja serta dedikasi yang kurang memadai bagi organisasinya.

\section{Kepribadian terhadap Budaya Organisasi}

Hasil penelitian menunjukkan secara nyata bahwa kepribadian berpengaruh secara positif dan signifikan terhadap budaya organisasi. Dalam arti semakin baik kepribadian yang dimiliki anggota suatu organisasi maka akan semakin baik pula budaya organisasi yang terbentuk didalamnya. Demikian pula sebaliknya, semakin tidak baik kepribadian yang dimiliki anggota suatu organisasi maka akan semakin tidak baik pula budaya organisasi yang terbentuk didalamnya.

Penelitian ini sejalan dengan pendapat Daft yang menjelaskan bahwa "kepribadian merupakan aspek atau bagian yang digunakan untuk mendeskripsikan pertumbuhan dan perkembangan pembelajaran seseorang sebagai bagian penting dari dasar kepemimpinan untuk mencapai tujuan yang diharapkan." ${ }^{24}$ Pengertian ini menunjukkan bahwa kepribadian merupakan bagian yang penting dalam proses kepemimpinan. Karena kepemimpinan menurut John Adair adalah" kemampuan mempengaruhi orang lain untuk mencapai tujuan bersama." ${ }^{25}$

Pengertian ini mengandung dua unsur pokok yaitu:Pertama; kemampuan mempengaruhi orang lain melalui berbagai cara, kedua; mencapai tujuan organisasi bersama orang lain. Hal ini berarti bahwa, kepemimpinan tidak akan terjadi kecuali terdapat hubungan saling mempengaruhi antara orangorang dalam satu organisasi dengan orang lain. Hal ini berarti bahwa; kepemimpinan tidak akan terjadi kecuali terdapat hubungan saling mempengaruhi antara orang-orang dalam suatu organisasi dengan orang lain. Siapa yang paling kuat pengaruhnya dalam suatu kelompok, akan menjadi pemimpin kelompok tersebut. Sedangkan anggota yang memiliki pengaruh yang lemah akan menjadi pengikut. Dalam hubungan dengan orang lain, maka kepribadian yang lebih baik sangat diperlukan untuk mendukung proses interaksi antara satu dengan yang

${ }^{24}$ Richard L. Daft, The Leadership Experience, (Canada: Thomson South West, 2004), h.190.

${ }^{25} \mathrm{John}$ Adair, Not Bosses But Leaders, (London: Great Britain Clesys ltd, 2003), h. 7. 
Zulkarnain S I Kemampuan Manajerial, dan Upaya Organisasi

lainnya.

Karena itu untuk mencapai suatu budaya organisasi yang mantap, yang dapat dipahami dan diterima internal maupun eksternal memerlukan kepribadian yang stabil, jiwa kepemimpinan yang jujur dan adil serta perilaku yang baik diantara anggota organisasi.Dengan demikian, budaya organisasi pun dapat berfungsi secara efektif dalam rangka mencapai maksud dan tujuan organisasi. Bahkan, budaya organisasi dapat menjadi landasan pengembangan pola kerja dan pola hubungan antara sesama anggota organisasi lain.

Karena itu untuk mencapai suatu budaya organisasi yang mantap, yang dapat dipahami dan diterima internal maupun eksternal memerlukan kepribadian yang stabil, jiwa kepemimpinan yang jujur dan adil serta perilaku yang baik diantara anggota organisasi.Dengan demikian, budaya organisasi pun dapat berfungsi secara efektif dalam rangka mencapai maksud dan tujuan organisasi. Bahkan, budaya organisasi dapat menjadi landasan pengembangan pola kerja dan pola hubungan antara sesama anggota organisasi lain.

\section{Kemampuan manajerial terhadap budaya organisasi}

Hasil penelitian menunjukkan bahwa kemampuan manajerial berpengaruh secara positif dan signifikan terhadap budaya organisasi. Semakin baik kemampuan manajerial yang dimiliki anggota suatu organisasi maka akan semakin baik pula budaya organisasi yang terbentuk didalamnya. Demikian pula sebaliknya, semakin tidak baik kepribadian yang dimiliki anggota suatu organisasi maka akan semakin tidak baik pula budaya organisasi yang terbentuk didalamnya.

Robbins dan Coulter menguraikan bahwa kemampuan manajerial meliputi; (1) Kemampuan konseptual. Kemampuan ini meliputi kemampuan menggunakan informasi, identifikasi peluang, memahami model organisasi dan model lain. (2) Kemampuan Komunikasi. Kemampuan ini meliputi kemampuan mengubah ide menjadi hal-hal yang lebih kongkrit berupa kata, mendengarkan dan mengajukan pertanyaan, kemampuan persentasi. (3) Kemampuan keefektifan. Kemampuan ini berupa berbagai tugas, bernegosiasi, mengulas operasi dan mengajukan perbaikan. (4) Kemampuan interpersonal. Kemampuan ini berupa kemampuan antar pribadi, memimpin dan membimbing, bekerja dengan orang yang berbeda budaya atau

\footnotetext{
${ }^{26}$ Robbins dan A. Judge, op cit. hh. 9-10.
}

karakter, membangun jaringan di dalam dan di luar organisasi. $^{26}$

\section{Kesimpulan}

Berdasarkan hasil analisis data dan perhitungan statistik seperti yang telah diuraikan, maka dapat diambil beberapa kesimpulan sebagai berikut :

Kepribadian berpengaruh langsung positif terhadap kinerja, Hal ini berarti bahwa kepribadian yang baik mengakibatkan meningkatnya kinerja dosen. Kemampuan manajerial berpengaruh langsung positif terhadap kinerja. Hal ini berarti bahwa kemampuan manajerial yang baik mengakibatkan meningkatnya kinerja dosen. Budaya organisasi berpengaruh langsung positif terhadap kinerja. Hal ini berarti bahwa budaya organisasi yang baik, mengakibatkan meningkatnya kinerja dosen. Kepribadian berpengaruh langsung positif terhadap budaya organisasi. Hal ini berarti bahwa kepribadian yang baik mengakibatkan meningkatnya budaya organisasi. Kemampuan manajerial berpengaruh langsung positif terhadap budaya organisasi. Hal ini berarti bahwa kemampuan manajerial yang baik, mengakibatkan meningkatnya budaya organisasi.

\section{Daftar Pustaka}

Kamaruddin Amin. "Kampus Masih Kekurangan Doktor". http://edukasi.kompas.com/ $\mathrm{read} / 2015 / 08 / 25 / 20210061 /$ Kampus.Masih. Kekurangan.Doktor. (diakses 7 Mei 2016).

Lihat Makalah: Percik Pengalaman Mengurus Jabatan Fungsional, disampaikan pada penataran Penilaian Angka Kredit Jabatan Fungsional Dosen, Kopertis Wilayah IV, 27-28 Mei 2003

Direktorat Jenderal Pendidikan Tinggi (Dikti), 2011. Wirawan, Evaluasi Kinerja Sumber Daya Manusia, Teori, Aplikasi, dan Penelitian (Jakarta: Selemba Empat, 2009)

Stephen P. Robbin, Essentials of Organizational Behavior (New Jersey: Prentice-Hall Internatioanl Inc, 1997)

Aban M. Mohrman, M. Resnick West, dan Edward E. Lawler, Designing Performance Appraisal Systems (San Francisco: Jossey Bass, 1989)

Micahel Amstrong dan Angela Baron, Performance Management (London: Institute of Personal and Depelopment, 1998)

Wibowo, Manajemen Kinerja (Jakarta: Rajawali pers, 2012)

Laurie J. Mullins, Management and Organizational Behavior, Seventh Edition (London: Prentice Hall, 2005)

Aban M. Mohrman, M. Resnick West, dan Edward E. 
Lawler, DesigningPerformance Appraisal Systems (San Francisco : Jossey Bass, 1989)

Micahel Amstrong dan Angela Baron, PerformanceManagement (London : Institute of Personal and Depelopment, 1998)

Wibowo, Manajemen Kinerja (Jakarta: Rajawali pers, 2012)

Gary YukI, Leadership in Organization. Fith Editation, alih bahasa Budi Supriyanto (Jakarta: Intan Sejati, 2005)

Benyamin Scheneider, Personality And Organizations. New York : Lawrence Ebaum Associate,
2004.

Richard L. Daft, The Leadership Experience, (Canada: Thomson South West, 2004), h.190.

John Adair, Not Bosses But Leaders, (London: Great Britain Clesys ltd, 2003), h. 7. 
Zulkarnain S | Kemampuan Manajerial, dan Upaya Organisasi 